\title{
Alternative Strategies for Controlling the Brown Locust, Locustana pardalina (Walker)
}

\author{
Roger Price
}

Citation: Price, R. Alternative Strategies for Controlling the Brown Locust, Locustana pardalina (Walker). Agronomy 2021, 11, 2212. https:// doi.org/10.3390/agronomy11112212

Academic Editors: Michel Lecoq and Arianne Cease

Received: 27 July 2021

Accepted: 31 August 2021

Published: 31 October 2021

Publisher's Note: MDPI stays neutral with regard to jurisdictional claims in published maps and institutional affiliations.

Copyright: (C) 2021 by the author. Licensee MDPI, Basel, Switzerland. This article is an open access article distributed under the terms and conditions of the Creative Commons Attribution (CC BY) license (https:// creativecommons.org/licenses/by/ $4.0 /)$.
Insect Ecology Division, ARC-Plant Health and Protection, Private Bag X134, Queenswood, Pretoria 0121, South Africa; pricer@arc.agric.za

\begin{abstract}
Regular and often intense outbreaks of the brown locust, Locustana pardalina (Walker), in the semi-arid Nama Karoo region of South Africa present a formidable pest control problem. Outbreak patterns over a 64-year period (1941-2005) were reviewed indicating a very high frequency of outbreak years with regular 'plague' periods being experienced, while a more detailed analysis of the numbers of locust targets controlled during a 22-year period (1983-2005) described the intensity and scale of the outbreaks. The operational constraints associated with the traditional ground-based control strategy employed against the thousands of individual roosting brown locust hopper band and swarm targets in the Karoo are discussed. A brief review of laboratory and field trials of alternative methods of controlling the brown locust, such as insecticide baits, barrier treatments and the Green Muscle ${ }^{\circledR}$ myco-insecticide, as an alternative to broad-spectrum pyrethroid insecticides are described. In addition, alternative control strategies to the current 'Commando' system of ground-based control operations are discussed. The recommendation is for a modernised and technology-equipped integrated brown locust management strategy (IPM), combining ground and aerial tactics that will have the flexibility and the capacity to deal effectively with outbreaks. The integrated management strategy should focus on ground-based control of hopper bands and fledgling swarms in the Upper and eastern Karoo, while outbreaks over most of the Central Karoo and arid Bushmanland areas should be left to fledge and coalesce into large-sized swarms that could then be targeted by spray aircraft as they migrate along their known swarm flight paths. The introduction of electronic reporting and GIS mapping technologies for brown locust campaign management is essential.
\end{abstract}

Keywords: brown locust; Locustana pardalina; Karoo; outbreak patterns; control strategy; integrated pest management

\section{Introduction}

The aim of this review article is to summarise the outbreak history of the brown locust, Locustana pardalina (Walker) along with the control tactics currently employed and alternative control methods evaluated, and to then discuss possible alternative strategies for more effective management of outbreaks. The brown locust has a recognised outbreak area that covers approximately $250,000 \mathrm{~km}^{2}$ of the semi-arid Nama Karoo biome region of South Africa and southern Namibia [1-4], from where plagues have developed that have overrun the entire southern African sub-continent up to the Zambezi River [3]. The Nama Karoo occupies the central plateau of the western half of South Africa at an altitude of 500-2000 m, so frost is common in winter. The rainfall mainly falls in late summer and autumn, with a rainfall gradient ranging from approximately $100 \mathrm{~mm}$ in the western arid areas to $400 \mathrm{~mm}$ per annum in the eastern Karoo, although rainfall is typically erratic and extended droughts are common. The brown locust displays a wide range of phase polymorphism and sexual dimorphism [5], with the differences measured between the extreme solitaria and gregaria phases being more pronounced than with any other locust species [6,7]. The field biology and population dynamics of the brown locust have been extensively studied [2,8-13]. An 
important aspect of the brown locust lifecycle for survival in the semi-arid Karoo is the egg stage, which is highly resistant to drought involving a complex of diapause and quiescent stages [14]. Solitaria phase females only lay diapause eggs, with the obligate diapause being broken after 9-45 days under dry soil conditions, while gregaria swarming females only lay non-diapause eggs that develop continuously under moist soil conditions. Transient phase females lay egg pods containing various proportions of diapause and non-diapause eggs depending upon factors including day length, phase, age and nutrition of the female [14]. Under extended dry conditions in the Karoo, the non-diapause eggs, as well as the diapause eggs that have exited the diapause state, stop further development and enter a state of quiescence just before the embryonic stage of katatrepsis takes place [14]. Quiescent eggs are known to be very drought tolerant and small numbers of egg pods have been known to survive for up to $2-3$ years in the field $[9,15]$, Price, pers. obs., but the contribution of any eggs surviving for more than 12 months was dismissed as being irrelevant to the population dynamics of the brown locust [15]. Eggs are typically laid in dry soil and hatch after 10-14 days following summer rainfall, with 20-25 mm of rain required for widespread hatching [10]. There are five hopper instars, with solitaria hoppers developing within 21-30 days depending upon temperature, while gregaria phase hoppers are much larger with the hopper bands typically taking 42-45 days to develop in summer [10,16]. Gregarious phase females in the field mature within 2-3 weeks after fledgling and will then lay 3-4 egg pods containing a mean of 45 eggs at weekly intervals [17], but under laboratory conditions the females mature more quickly and can lay up to 10-15 egg pods each [8]. Adult locusts live for 2-3 months under summer conditions, but live a lot longer during the cooler autumn season [8]. The multivoltine lifecycle along with a high fecundity of the brown locust allows a rapid rate of population increase with two or three generations normally possible per year from September to May [10], with four generations recorded during some of the more climatically favourable years [3], Price, pers. obs.

The brown locust is predominantly graminivorous and hoppers and adults prefer to feed on a range of Karoo grasses, but under dry field conditions the hoppers and adults can be frequently observed nibbling on the leaves and bark of Karoo bushes and anything else that is edible $[10,11,16]$. Eruptions of the brown locust pose a direct pest threat to the sheep grazing rangeland within the Karoo, to crops planted under irrigation within the Karoo, and more especially to the main maize and wheat cereal cultivation areas of the country that are within range of swarms escaping from the eastern Karoo. The brown locust therefore is a formidable pest problem and has been the target of chemical control campaigns waged by the South African Department of Agriculture since $1906[18,19]$.

The historic periodicity of brown locust plague periods from 1797 to 1915 were reported by Lounsbury [20] as lasting an average of 13 years with a recession period of approximately 11 years between the plagues. After the introduction of Governmentfunded chemical control in 1906, the periodicity of outbreak cycles was considered to have shortened to 7-11 years of swarming activity followed by a similar period of recession $[3,5,12,21,22]$. However, gregarious brown locust populations requiring chemical control could be found somewhere or other in the Karoo in approximately $90 \%$ of years throughout the entire twentieth century, although the intensity and extent of outbreaks varied greatly [19]. The outbreak and invasion areas of the brown locust in southern Africa as described by different authors are depicted for reference in Figure 1. 


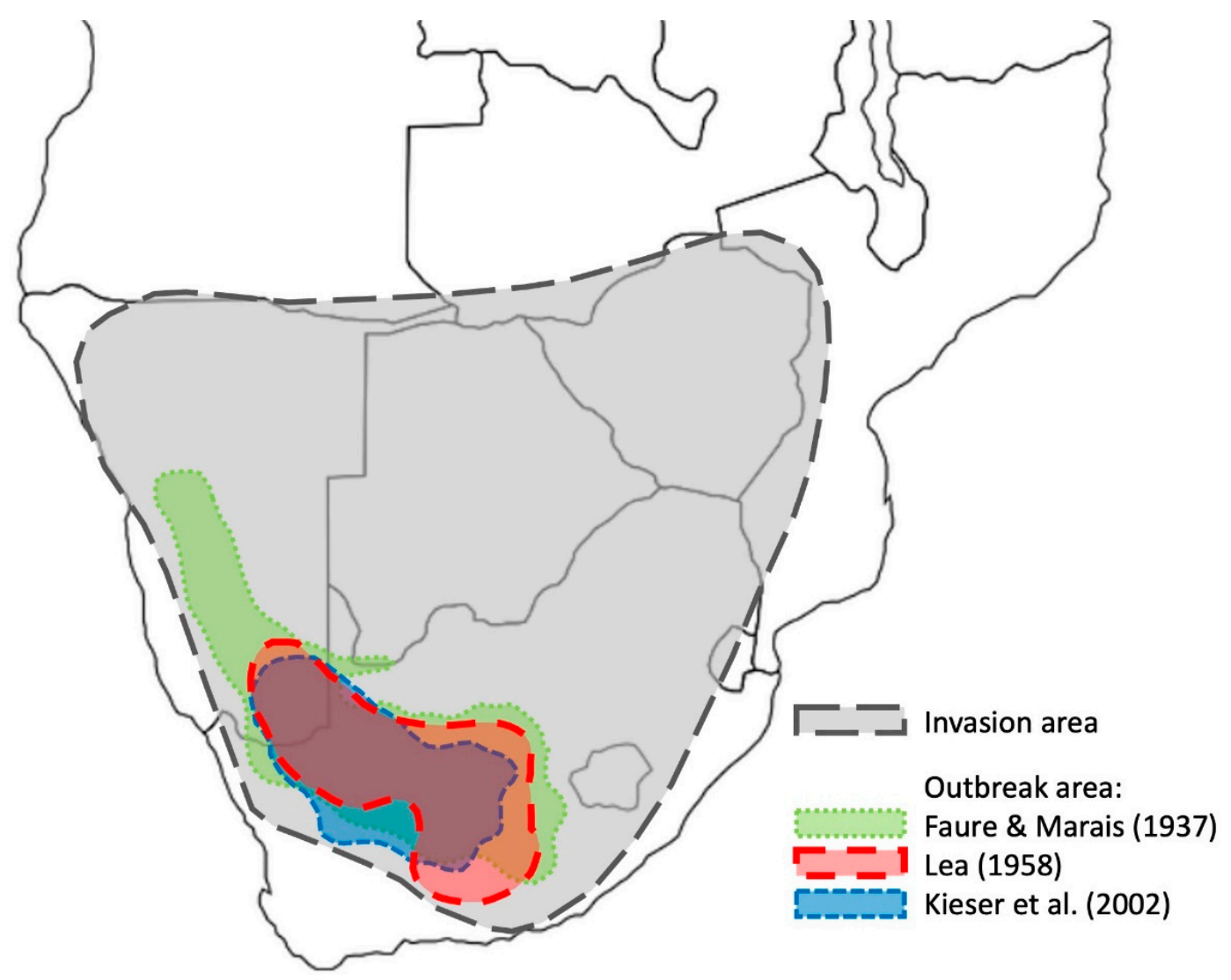

Figure 1. Outbreak area of the brown locust in southern Africa, as defined by Faure and Marais [1], Lea [3], Kieser [4]. Invasion area as defined by Lea [3].

\section{History of Brown Locust Outbreaks and Control}

\subsection{Outbreak Cycles of the Brown Locust}

Incipient outbreaks develop following the successful breeding and aggregation of solitary and transient phase adults leading to rapid gregarization of the next generation of hatching hoppers. Under favourable rainfall conditions over one or more summer seasons, such incipient outbreaks often develop simultaneously over a vast area of the Nama Karoo [5]. The scattered outbreaks rapidly develop into gregaria-phase population eruptions, which then have been traditionally combated at source within the Karoo [3], in a suppressive control strategy that can be described as upsurge elimination [23] before migrating swarms can escape and threaten cereal crop production areas outside the Karoo. Since the mid-1940s, when synthetic insecticides first became available, this control strategy has largely restricted outbreaks to the Karoo with only brief invasions of surrounding countries being recorded [19]. Long-term plague cycles have been prevented and food security within the southern African region has not been seriously threatened.

The distribution and abundance of brown locust populations for the period 1906-1969 were described by Lea [12,21,22], with the relative abundance per year based on figures of control expenditure. However, financial comparisons become inaccurate over time and a more comparative analysis of brown locust outbreaks was considered to be the number of Magisterial Districts that reported locust control action per year in South Africa, Namibia and Botswana [19], although this number gave no indication of the actual intensity of the outbreaks within each of the districts. An updated graph of the number of Magisterial Districts where control action was undertaken between 1941 and 2005 is shown in Figure 2. 


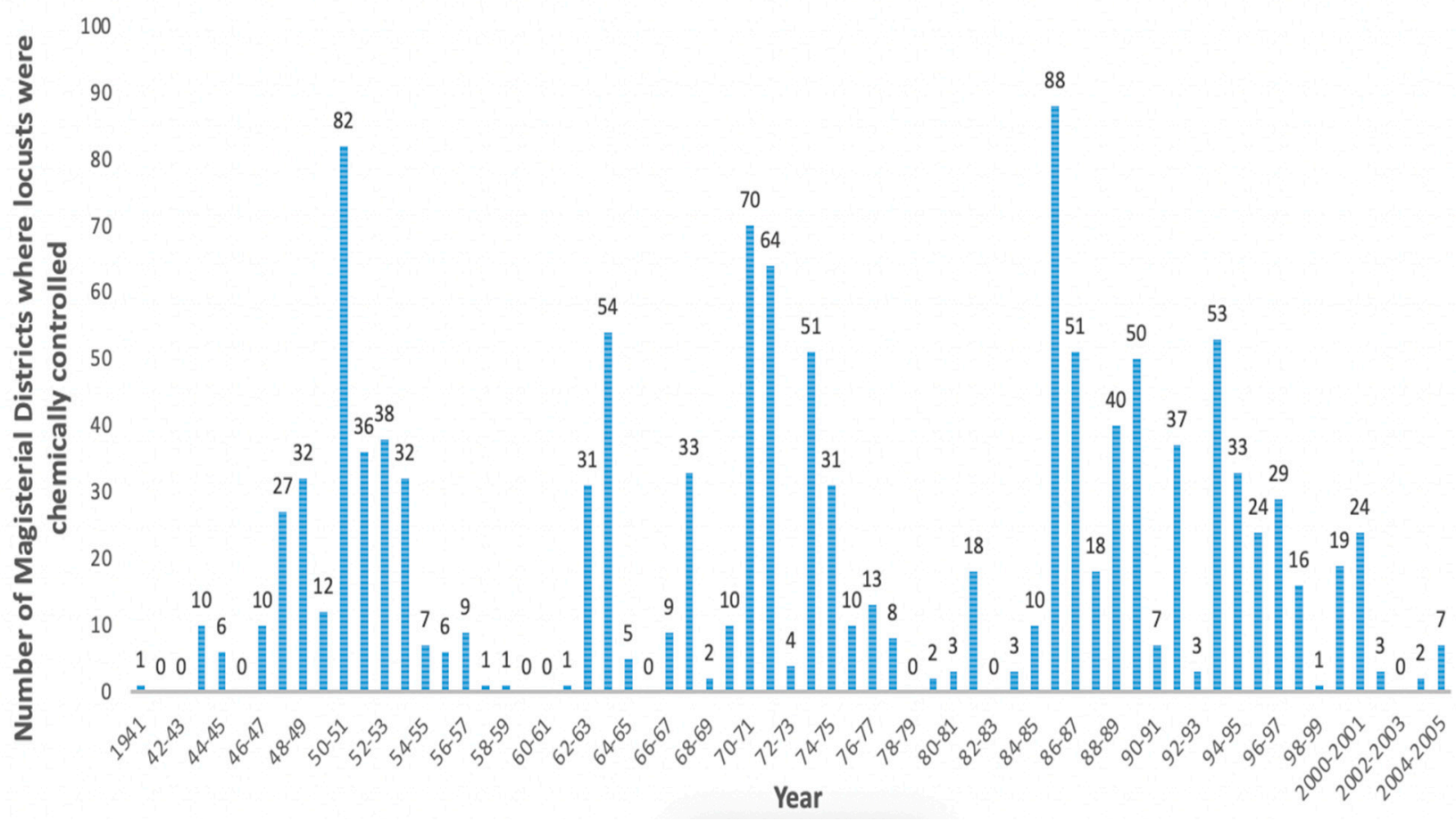

Figure 2. Number of Magisterial Districts that reported brown locust campaigns per locust season in South Africa, Namibia and Botswana between 1941 and 2005. Data obtained from Lea [3,22] for the period 1941-1954, from Lea [13,22] for the period 1954-1969, from annual reports of the South African National Dept. Agric. between 1970 and 1984, and from weekly locust control reports from the South African Dept. Agric. for the period 1984-2005. Data for Namibia and Botswana from Lea [22] and from Dept. Agric. reports from 1985 to 2005.

Figure 2, shows the high outbreak frequency and occurrence of major eruptions or 'plague' periods over a wide area, namely during the periods 1950-1951, 1963-1964, 1970-1975, 1985-19787, 1988-1990, 1993-1997 and 1999-2001. The actual intensity of the brown locust control campaigns can be demonstrated from more recent records of the number of individual locust targets chemically controlled during each 'locust outbreak season' (September-June) over the 22 year period in South Africa between 1983-1984 and 2004-2005 (Table 1).

Intense outbreak seasons can be clearly seen (Table 1), with 'plague' eruptions, as defined by the Southern African Regional Commission for the Conservation and Utilization of the Soil (SARCCUS) sub-committee for the control of migratory pests [24] as seasons with $>5000$ adults swarms being controlled, being evident in 1985-1986, 1988-1989, 1993-1994, 1995-1996, 1996-1997 and 1999-2000. The continual chemical control campaigns waged against the brown locust have evidently not dampened the ability of this locust species to produce serious eruptions on a regular basis [22], with enough of the gregarious populations surviving to lay eggs before winter to ensure the ongoing eruption into the next season [19]. It is evident that the preventative control action, in the sense of stopping the plagues from developing, has utterly failed [22]. The ever increasing economic costs of the almost annual control campaigns, as well as the environmental contamination that is inevitably caused by the application of broad-spectrum insecticides in the ecologically unique Nama Karoo biome, is a serious cause for concern and introspection. 
Table 1. The number of individual locust targets (roosting hopper bands and adult swarms) controlled during each outbreak season (September to June) in South Africa between 1983-1984 and 2004-2005 (data from the weekly reports of the locust control officers of the South African National Department of Agriculture).

\begin{tabular}{|c|c|c|}
\hline Outbreak Season & $\begin{array}{l}\text { No. Hopper Bands } \\
\text { Controlled }\end{array}$ & $\begin{array}{l}\text { No. Adults Swarms } \\
\text { Controlled }\end{array}$ \\
\hline 1983-1984 & 61 & 34 \\
\hline 1984-1985 & 633 & 65 \\
\hline $1985-1986$ & 175,500 & 38,600 \\
\hline 1986-1987 & 68,902 & 14 \\
\hline 1987-1988 & 5618 & 1123 \\
\hline 1988-1989 & 85,935 & 1642 \\
\hline 1989-1990 & 36,553 & 1392 \\
\hline 1990-1991 & 1142 & 357 \\
\hline 1991-1992 & 18,131 & 1603 \\
\hline 1992-1993 & 72 & 0 \\
\hline 1993-1994 & 34,581 & 9565 \\
\hline 1994-1995 & 20,895 & 663 \\
\hline 1995-1996 & 24,489 & 6577 \\
\hline 1996-1997 & 75,890 & 8081 \\
\hline 1997-1998 & 1018 & 80 \\
\hline 1998-1999 & 2 & 0 \\
\hline 1999-2000 & 40,115 & 9021 \\
\hline 2000-2001 & 28,642 & 1135 \\
\hline 2001-2002 & 1905 & 137 \\
\hline $2002-2003$ & 0 & 0 \\
\hline 2003-2004 & 128 & 154 \\
\hline $2004-2005$ & 1167 & 20 \\
\hline
\end{tabular}

\subsection{Control Strategy against the Brown Locust in South Africa}

Due to the devastation caused to agriculture in South Africa at the turn of the 20th century by incessant locust plagues, the South African Government first took over the coordinated responsibility for locust control in 1906 using sodium arsenite solutions ('arsenite of soda' dissolved in warm water with sugar added) applied using spray pumps [18]. Sodium arsenite aqueous and dusting formulations were used for brown locust control for the next 30 years, even though the toxicity of arsenic compounds to the spray operators and livestock was already well known with safe handling and operator protection regulations being issued [25]. Plague locusts were declared as National Pests in South Africa in 1911 in one of the first legislations promulgated by the new Government of the Union of South Africa [20]. The national pest status of locusts and the legal responsibility of landowners to report the presence of locusts on their land and for the Minister of Agriculture to be responsible for combatting locust outbreaks was ratified under Article 6 of the South African Migratory Pests Act (Act No. 36 of 1983). The principles guiding locust control in South Africa were updated and consolidated in a new policy for the management of the locust problem in South Africa [26]. The National Department of Agriculture, Land Reform and Rural Development: Directorate of Disaster Management, who are responsible for locust control, currently maintains two locust control depots in the Nama Karoo, namely at De Aar in the Upper Karoo region and at Upington in the arid Bushmanland region, managed by a 
senior locust control officer at each depot who controls the stores of application equipment and pesticide stocks.

The pro-active control of incipient sub-swarming brown locust concentrations has historically been considered as being uneconomic and impractical $[5,12,22]$ and brown locust control has always relied on an emergency response to swarming populations. Due to the seasonal nature and unpredictable location of brown locust outbreaks, the operational management of outbreaks has relied for decades on what is locally known as the "Commando system", which activates during outbreaks with an army of temporarily employed locust officers and spray machine operators tracking down and controlling individual hopper band or roosting swarm targets. The Directorate maintains a network of District Locust Control Officers in each of the Magisterial Districts within the brown locust outbreak region, who are usually farmers with previous experience with locust control campaigns and who are re-appointed during outbreaks in order to coordinating the control campaigns in their District by directing control teams and managing pesticide and equipment resources. These officers report any control actions directly to the Senior Officers at the two locust control depots. Farmers and town residents from the local communities within each of the districts are then appointed on a temporary basis as 'supervisors/drivers', who use their own private pick-up vehicles for undertaking the locust control operations and who then claim a mileage allowance rate. The supervisor/drivers then appoint a small team of pest control operators (usually local farm assistants) to manage the spray machines. The district locust officers, supervisors and assistants also claim day-wage allowances when on active duty [27]. The supervisors and assistants receive protective clothing and training on the effective and safe operation of the spray equipment.

Brown locust control currently relies on the ground-based spot application of broadspectrum, fast-acting synthetic pyrethroid insecticides, such as deltamethrin (Decis ${ }^{\circledR}$ ) UL $6 \mathrm{~g}$ a.i. $/ \ell$, and more recently esfenvalerate (Sumi-Alpha ${ }^{\circledR}$ ) UL $8 \mathrm{~g}$ a.i. $/ \ell$ ), applied at an area dosage rate of $2.5 \ell /$ ha as low-volume drift sprays from motorised knapsack sprayers (Solo Port $423^{\circledR}$ ) or vehicle mounted (Power Solo ${ }^{\circledR}$, Francisco 'Bakkie' pump ${ }^{\circledR}$ and Micron Ulvamast ${ }^{\circledR}$ ) equipment [27]. The vehicle-mounted sprayers are used to control the larger-sized targets. In some areas, esfenvalerate (Sumi-Alpha DP ${ }^{\circledR}$ ) dusting powder is applied at rates of $5-20 \mathrm{~kg} / \mathrm{ha}$ using manual backpack dusters or motorized powder dusters (Osbornbirds ${ }^{\circledR}$ ). Individual hopper band and fledgling swarm targets are located by the mobile control teams and are spot-treated early in the morning while still densely aggregated on their overnight roosts and while basking in the morning sun. Hopper control is focussed on the later instar (L4-L5) gregarious hopper bands which are red and black in colour, known locally in Afrikaans as 'rooibaadjies' (red jackets). Roosting band targets can be readily spotted with the naked eye or through binoculars over a distance of up to $1-2 \mathrm{~km}$ in the early morning sunshine as red-coloured masses roosting on the low Karoo bushes (usually $0.3-1 \mathrm{~m}$ high). Adult swarms are usually tracked by the locust officers and farmers during the afternoon until they roost on the Karoo bushes in the evening and are then controlled from vehicles during the night as this provides more time to complete the control operations against these often large targets [19].

Brown locust hopper band targets are usually small and discrete, measuring between $5 \mathrm{~m}^{2}$ and 0.5 ha in extent when roosting over the Karoo bushes, with $>90 \%$ of hopper band targets being $<0.25$ ha in extent [28]. The Department of Agriculture classifies small band targets as $<120 \mathrm{~m}^{2}$, medium targets as $121-2500 \mathrm{~m}^{2}$ and large targets as $>2500 \mathrm{~m}^{2}$, while roosting adult swarms average $10-14$ ha in extent, but can sometimes cover $2-3 \mathrm{~km}^{2}$. The aerial spraying of locust targets using spray helicopters and fixed-wing aircraft is generally unsuitable for use against the typically small-sized brown locust targets, but aerial control is employed during emergencies if the ground teams are being overwhelmed by the numbers of locust targets or if they occur in terrain which is difficult to access, or if fast-flying swarms are starting to exit the Karoo and to potentially threaten crops. The Department of Agriculture maintains a spray aircraft and spray helicopter on a stand-by contract, but emergency aerial support is also contracted from commercial crop spraying 
companies when required. The aerial control of flying swarms (air-to-air spraying) is not undertaken in South Africa.

The history of the methods and insecticide products used for brown locust control are described in Table 2. Apart from the insecticides used operationally for locust control in the Karoo, a wide range of insecticide products have also been screened as possible acridicides since 1975 against the brown locust $[19,28]$. Please note that mention of trade names of spray equipment and commercial insecticide products in this review publication is for the purpose of providing specific information only.

Table 2. History of the methods and insecticide products used for brown locust control operations in South Africa (from the South African National Department of Agriculture and [19,28]).

Mechanical and cultural control methods

Before 1906 (trampling, beating, burning pastures, digging up of egg beds, collecting adult locusts in sacks, spraying soap solutions)

Application of sodium arsenite

1906-1934 (supplied free of charge to farmers and applied as aqueous or dusting formulations using hand-operated pumps)

1934-1944

Sodium arsenite baits

(moistened bran bait applied by hand to roosting hopper bands)

Benzene hexachloride (BHC)

1945-1986 (applied first as a bait agent and as aqueous spray, but mainly as a dust formulation (mainly 7\% gamma isomer, but also as Lindane dust with $99 \%$ gamma BHC formulation), applied as a dusting powder from hand-operated or motorised dusting machines at area application rates of $15-20 \mathrm{~kg} / \mathrm{ha}$ )

Organophosphate insecticides

1975-1994 (diazinon and fenitrothion applied as an ultra-low-volume (ULV) sprays from a range of motorised mist-blower and stacked-disc sprayers). A standard $400 \mathrm{~g} / \ell$ fenitrothion formulation was applied at a volume rate of $2.5 \ell / \mathrm{ha}$, giving an area dose rate $1 \mathrm{~kg}$ a.i. $/$ ha

Synthetic pyrethroid insecticides

1990-to date

(deltamethrin and esfenvalerate applied as ULV spray at a volume rate of $2.5 \ell /$ ha from motorised back-pack or vehicle-mounted sprayers). Esfenvalerate UL $8 \mathrm{~g}$ a.i. $/ \ell$ formulation is now mainly employed in the Karoo

Future

New products already registered or trial work completed (e.g., alpha-cypermethrin, fipronil, Metarhizium myco-insecticide)

\subsection{Outbreak Early Warning Systems}

The complicated relationship between the patchy rainfall distribution typical in the semi-arid Karoo areas and the development of incipient outbreaks has been studied for decades $[2,3,10,12]$, but no conclusive patterns were found to enable an effective outbreak early warning system to be developed. Both Smit and Lea clearly thought that drought conditions of dry winters and dry early-summers, followed by widespread rainfall in latesummer, supported large-scale population increases, whilst fewer outbreaks were recorded following wet winters and wet early-summer periods. By analysing the correlations between rainfall data and swarming activity for the development of an outbreak simulation model [29], the data supported the view that dry winters followed by good early rains in the Karoo were conducive to years of locust eruptions, while wet winters were conducive to years of reduced locust numbers. The hypothesis was that the dry conditions over several months, with no rain on any one day of more than $6 \mathrm{~mm}$, ensured that both diapause and quiescence in the overwintering egg populations was broken and allowed the eggs to respond to rainfall events in early summer (October-December). However, this simulation model relied on estimates of egg populations to generate outbreaks and the reliability of such detailed field data will always be problematic. However, other studies could find no statistical evidence of any connection between brown locust eruptions and previous austral winter rainfall [30], but instead found a high correlation between rainfall over 
the previous 12 months prior to the locust season and in particular with rainfall during December. The hypothesis was that the high-frequency outbreak cycles were related to the El Nino/Southern Oscillation (ENSO) climatic patterns and that high-frequency locust activity was clearly evident during La Niňa events (wet cycles in southern Africa) and with low locust activity during El Nino dry events. A dominant outbreak frequency of 17.3 years was proposed, with these extended cycles strongly related to the sea-surface temperatures and ENSO events [30].

The monitoring of farms with a known history of producing locust outbreaks was also employed for many years in the past as an early warning system of the build-up of solitary adult populations and the development of impending outbreaks $[10,12]$. The foot survey counts accurately predicted the development of incipient swarming populations based on critical population levels for phase transformation [12], but the monitoring was very time consuming and became redundant once widespread outbreaks developed.

\subsection{Environmental Impact of Synthetic Pyrethroid Insecticides}

Modern synthetic pyrethroid insecticides are safer to apply and pose less environmental risk than the arsenic, organochlorine and organophosphate compounds used for locust control in the past [31,32]. The tactics of the spot application of insecticide to densely aggregated, roosting brown locust targets also minimizes the area treated, compared with the aerial blanket-spraying undertaken against some other locust and grasshopper species.

As discussed previously, the roosting brown locust hopper band and swarm targets are usually relatively small and discrete, so only a limited area is actually spot-sprayed during control operations. Over a 20-year period, an estimated average of 75,000-90,000 ha were sprayed each year against the dense roosting targets during locust control operations in the Karoo, which is less than $0.25 \%$ of the total brown locust outbreak area [27]. Spot spraying with synthetic pyrethroids in the Karoo also has a relatively short-term environmental impact as most non-target arthropods recolonize the small treated areas within a few weeks in summer [33], while the chance that exactly the same areas are sprayed every year is also low [28]. Nevertheless, the intensity of the spraying campaigns and the negative impact that the repeated application of broad-spectrum insecticides may have on the rich diversity of endemic invertebrates and reptiles found in the Nama-Karoo biome is of concern to landholders and conservationists. How to reduce the insecticide load and minimize the environmental impact in the Karoo and yet at the same time control this serious agricultural pest has become a controversial issue. There is thus a need for more target specific and environmentally benign methods of controlling the brown locust as an alternative to the current spraying of broad-spectrum insecticides.

\section{Alternative Control Methods}

Various alternative methods of controlling the brown locust were evaluated against gregarious hopper populations in the Agricultural Research Council-Plant Health and Protection (ARC-PHP) laboratories in Pretoria and in small-scale field trials in the Nama Karoo between 1994 and 2003 [34].

\subsection{Natural Enemies}

A wide range of natural enemies are known to prey upon the various life stages of the brown locust $[9,21,35,36]$ and their impact can sometimes be locally high [9]. The predation of egg pods by larvae of the woolly bee fly, Systoechus sp. (Bombyliidae) and the digging up of egg beds by small mammals and birds sometimes caused up to $12 \%$ mortality of egg pods [34]. The voracious ants, Camponotus fulvopilosus and Anoploepis custodiens, were also sometimes important predators of hatching hoppers, while various species of robber flies, ground beetles, hunting wasps, scorpions, spiders, lizards, mammals (e.g., jackals, mongooses, feral dogs) and a wide range of bird species are opportunistic predators of all life stages of the brown locust [34]. Of particular interest was the impact of the sarcophagid fly, Wohlfarhtia pachytyli (Walker), which is a generalist scavenger as well as a facultative 
parasite of moulting L5 brown locust hoppers and fledglings [37]. The fly larviposits on moulting locusts when they are immobilised and unable to defend themselves from fly attack. In contrast, no parasitism of active hoppers or adults was observed [37,38]. The fly was common throughout the Karoo and highest fly populations were always associated with brown locust outbreaks. Locusts parasitised by fly maggots were regularly found at roosting sites where hopper bands had moulted, or where fledgling had occurred. However, intensive sampling showed that $W$. pachytyli failed to cause more than $0.1 \%$ mortality of hoppers and $6 \%$ mortality of fledgling swarms [38]. These figures suggest that the potential of W. pachytyli as a biological control agent may have been overestimated in the past [38]. Despite the wide range of opportunistic predators and parasites reported, their impact on brown locust populations was usually very low. On no occasion were natural enemies observed in sufficient numbers to dampen the intensity of brown locust outbreaks [34].

\subsection{Mechanical Control}

Before the first insecticides became available at the turn of the 20th century, farmers had to resort to beating, trampling, trenching and burning to protect their crops and pastures from the ravages of locusts $[18,39]$. Turning back the clock, the destruction of locust egg beds and the harvesting of locusts were re-examined as control methods. Brown locust egg beds proved very difficult to locate in the remote Karoo, but once found, the excavation of locust eggs with picks and garden forks gave excellent control. However, the disturbance of the friable soils in the Karoo would cause severe erosion problems and is therefore not advocated. Harvesting of live locusts using nets or vacuum machines was not practical as locusts either scattered upon disturbance, or retreated into the interior of the spiny Karoo bushes to avoid capture. However, the harvesting of locust cadavers lying on the soil surface following insecticide spraying, once they had dried out and insecticide residues had broken down, was possible. With their high protein and fat content, the processing of locust cadavers into animal feed may become economically viable in future.

\subsection{Insecticide Baits}

Bran bait containing 2-3\% sodium arsenite was extensively used for the control of brown locust and red locust hopper bands in South Africa during the 1930s [40]. The baiting technique was re-evaluated as a more target-specific, low cost method of locust control using two modern insecticides, the non-ester pyrethroid, silafluofen (Neophan ${ }^{\circledR}$ ), and the phenyl-pyrazol, fipronil (Regent ${ }^{\circledR}$ ). Bioassays showed that these insecticides, when dissolved in water and mixed into wheat bran as the edible carrier, had a potent stomach action and were effective in minute quantities against the brown locust. Bran baits containing $0.2 \%$ Neophan $80 \mathrm{EC}$ and $0.02 \%$ Regent $200 \mathrm{SC}$ were prepared in the field and were broadcast by gloved hand onto the soil surface around bushes occupied by hopper bands as overnight roosting sites [34,41]. The densely aggregated hoppers descended from their roosts to bask at the base of the bushes and fed avidly on the bait. Hoppers became visibly affected within $2-3 \mathrm{~h}$ and usually died within $24 \mathrm{~h}$.

Batches of 5 and $10 \mathrm{~kg}$ of both baits gave excellent control (>95\%) of small and medium sized hopper bands roosting over an area of $10-100 \mathrm{~m}^{2}$ and $101-250 \mathrm{~m}^{2}$, respectively. However, baiting was only effective if undertaken shortly after sunrise, before hoppers descended from their roosts and scattered from the baited area. Baiting large bands or diffuse targets, or baiting later in the day once hoppers became active, was not effective [41]. Baiting was more practical under autumn conditions in the Karoo when there was more time during the cool mornings to locate and bait bands before they descended from their roosts. Baiting was inexpensive and was easy to prepare and apply, requiring basic equipment and limited training. Baiting was also a more target-specific method of controlling locusts as there was no off-target drift of insecticide and it only killed the hoppers and some other insects that ate it. Baiting could thus be effectively used for small-scale locust control by rural communities, or in conservation areas where more target-specific 
locust control is required [34]. However, the logistics of the bulk transport, preparation and application of locust baits under large-scale operational conditions appear daunting.

\subsection{Insecticide Barrier Treatments}

Barrier treatments, based on the application of the organochlorine insecticide, dieldrin, applied to narrow strips of vegetation were extensively used in North Africa to control marching bands of the desert locust [42]. Following the withdrawl of dieldrin during the 1970s due to its high persistence and bio-accumulation in the environment [43], the most promising candidates to have emerged as a replacement for dieldrin in barrier treatments have been various insect growth regulator (IGR) compounds and the phenyl pyrazole insecticide, fipronil. These compounds provide moderate persistence in the environment without the bio-accumulation problems of dieldrin [23]. In recent years, fipronil (Adonis $\mathrm{UL}^{\circledR}$ ) barriers have been successfully applied from aircraft under operational conditions against hopper bands of the Malagasy locust, the Australian plague locust and the desert locust. However, insecticide barrier treatments have never been used operationally against the brown locust.

The high efficacy of fipronil against the brown locust was established in laboratory bioassays and in small-scale field trials of ULV cover sprays. Field trials of fipronil (Adonis ${ }^{\circledR}$ $5 \mathrm{UL}$ ) barriers, applied to $21 \mathrm{~m}$-wide strips of Karoo vegetation at a volume rate of $2.5 \ell /$ ha (giving an area dose rate of $12.5 \mathrm{~g}$ a.i./ ha) from motorized 'Solo 432' knapsack sprayers, were used to intercept marching gregarious brown locust hopper bands. Barriers of Adonis ${ }^{\circledR}$ applied at $12.5 \mathrm{~g}$ a.i / ha proved very effective against L2-L3 bands and against small-size L4-L5 bands, giving $>90 \%$ control within $48 \mathrm{~h}$ [34]. However, a lower dose rate of $7.5 \mathrm{~g}$ a.i./ha in similar barrier strips proved largely ineffective against L3-L5 marching bands. Even at the high $12.5 \mathrm{~g}$ a.i./ ha dose rate, the barriers sometimes failed to adequately control large and mobile L5 hopper bands that maintained cohesion and had sufficient momentum to march quickly through the relatively narrow barrier strips before the majority of hoppers acquired a lethal dose. For maximum efficacy it was vital that hoppers consumed fipronil-treated vegetation and barriers proved less effective where the vegetation density was sparse or where the vegetation was less palatable to hoppers [34].

Despite these factors, Adonis ${ }^{\circledR}$ barriers were considered to have potential for the passive control of brown locust hopper bands in the more remote western areas of the Karoo, especially during the early stages of an outbreak when young-instar hopper bands become mobile. The high mobility of the hopper bands, which can march at least $1-3 \mathrm{~km}$ per day in summer, would suggest that even a low-density network of insecticide barriers, set $5-10 \mathrm{~km}$ apart, would soon be intercepted by marching bands. However, the fipronil product has a comparatively high environmental impact against non-target organisms, with the product assigned a high-risk rating by the FAO against terrestrial non-target organisms and a medium risk against mammals, reptiles and aquatic arthropods [44]. This is a similar environmental risk rating as malathion, which is extensively applied as an area treatment against the desert locust. The FAO Pesticide Referee Group recommends a dose rate of $4.2 \mathrm{~g} /$ ha Adonis ${ }^{\circledR}$ for wide barrier treatments applied from aircraft against other locust and grasshopper species [44]. Any barrier treatments would have to be judiciously applied to restrict the environmental impact of Adonis®against non-target organisms in the Nama Karoo environment.

\subsection{Insect Growth Regulators (IGRs)}

The benzoylphenyl urea IGR products only affect the juvenile stages of insects and are thus relatively target specific with a limited environmental impact [45]. Various IGRs have been used operationally as barrier treatments or cover sprays against a number of locust and pest grasshopper species [23]. Laboratory bioassays with the IGRs, flufenoxuron and teflubenzuron, applied to maize leaf discs and fed to L5 brown locust hoppers at dose rates of $3-15 \mu \mathrm{g} / \mathrm{g}$ per hopper, gave variable mortality of $30-70 \%$ after a single ingestion [34]. However, when diflubenzuron (Dimilin $\mathrm{OF}^{\circledR}{ }^{\circledR}$ ), was sprayed onto maize 
plants at volume rates of $1-3 \ell /$ ha and subsequently fed to $\mathrm{L} 2$ hoppers, $100 \%$ mortality of hoppers was produced within 11 days at all application rates as long as the hoppers were continuously exposed to treated vegetation. However, irregular exposure to Dimilin ${ }^{\circledR}$ during the inter-moult period produced unsatisfactory mortality, as the product is evidently non-accumulative and is readily excreted [46]. The fact that brown locust hoppers have to feed regularly on IGR-treated vegetation during the entire inter-moult period, combined with the high mobility of hopper bands, would probably make IGR barriers unsuitable for brown locust control operations. To increase the likelihood of hoppers ingesting treated vegetation, large areas would have to be block-treated from aircraft, or multiple barriers would have to be applied in parallel across vast tracts of the Karoo. These application strategies are clearly uneconomic and are not environmentally acceptable.

\subsection{Metarhizium Myco-Insecticide}

Myco-insecticides, comprising the aerial conidia of certain isolates of the entomopath ogenic fungus, Metarhizium acridum ((Driver and Milner) J.F. Bisch., Rehner and Humber), formulated in oil and applied through conventional spray equipment, have proved effective against a range of locust and pest grasshopper species [47,48]. Myco-insecticides have a low environmental impact and are recommended for locust control in environmentally sensitive areas as replacements for synthetic insecticides [49]. Commercial myco-insecticide products have been shown to be effectively in large-scale operational use against the Australian plague locust, as well as against locust outbreaks in China [50]. Such products have also been used on occasion against the red locust and desert locust.

Under suitable application conditions the M. acridum (LUBILOSA isolate IMI 330189) myco-insecticide, applied at a standard dose of $100 \mathrm{~g}$ conidia/ha from hand-held ULV spinning disc apparatus, or from microlight aircraft fitted with micronair AU 4000 atomisers, regularly produced $>90 \%$ mortality of L5 brown locust hoppers sprayed in the field and then maintained in cages [51,52]. However, speed of kill was slow, with median lethal times of 10-13 days for the ground and aerial application trials, respectively. In most cases, acceptable $>90 \%$ mortality was not achieved for at least three weeks after application, although affected hoppers did show reduced feeding behaviour [53]. Despite the slow speed of kill in the small-scale trials, the myco-insecticide agent was considered a significant advance in brown locust control and was commercially registered as Green Muscle ${ }^{\circledR}$ in South Africa in 1998 under the South African Agricultural Remedies Act (Act 36 of 1947). However, subsequent studies showed that various factors negatively affected the performance of Green Muscle ${ }^{\circledR}$ against the brown locust. The hot and dry Karoo environment, combined with the high ultra-violet radiation typical of the latitude and altitude of the Karoo, is detrimental for the survival and transmission of fungal conidia. The most important constraint, however, proved to be the unusually active thermoregulation behaviour of brown locust hoppers in the field that enabled them to elevate and maintain their body temperature $2-3{ }^{\circ} \mathrm{C}$ above normal [54]. This 'behavioural fever' elevated the body temperature of the locust above the threshold for optimum growth of the fungal pathogen and effectively suppressed the development of mycosis under certain field conditions for up to 70 days [55]. The great variability of performance of the myco-insecticide was not evident in the cage samples taken during the earlier trial work, as the caged locusts were unable to thermo-regulate to the same extent to defer the onset of mycosis. This unfortunately gave a false impression of the true speed of kill in the field.

The lack of a rapid knock-down action and the slow speed of kill currently makes Green Muscle ${ }^{\circledR}$ unsuitable for spot spraying operations in the Karoo. The thousands of individual hopper bands treated during control campaigns, and the high mobility of marching bands, would make the easy recognition of treated and untreated targets by locust officers impossible. Its use in conservation areas is also currently not practical, as treated bands would soon march out of these relatively small and fragmented areas. An alternative application strategy to manage the slow speed of kill needs to be developed and tested, before Green Muscle ${ }^{\circledR}$ can be considered for brown locust control. 


\subsection{Pathogenic Micro-Organisms}

Apart from entomopathogenic fungi, a range of other pathogenic micro-organisms have been isolated from locusts and grasshoppers, including bacteria, entomopoxvirus, microsporidia, protists and nematodes [56]. Biological control of locusts and grasshoppers using the augmentative release of pathogens has met with mixed success [57] and has been considered as being impractical because of the technical problems and expense involved in the mass production and application of pathogens.

Various strains of the spore forming bacteria, Bacillus thuringiensis Berliner (Bt), have been commercialised world-wide as microbial insecticides against various Lepidoptera, Coleoptera and Diptera pests. However, none of the commercially available Bt strains has proved sufficiently pathogenic against locusts because of the acid $\mathrm{pH}$ of the Orthoptera gut which prevents the Bt endotoxin crystals from dissolving [58]. In bioassays against the brown locust, four Bt strains that showed an enhanced acid-tolerance were fed to L3 and L4 brown locust hoppers as freeze-dried Bt spores mixed into bran bait at a dose rate of $1 \mathrm{mg}$ spores/g dry bran. However, none of the Bt baits produced any significant mortality compared with the untreated controls [34].

Another pathogenic micro-organism evaluated against the brown locust was an entomopoxvirus (EPV) isolated from a West African grasshopper, Odaleus senegalensis (De Geer), which had shown potential for the control of some rangeland grasshopper pests in the western USA [59]. However, bioassays of the virus suspension applied to maize leaf discs and fed to different brown locust hopper instars at a range of dosage rates did not produce any observed infection or mortality compared with untreated controls [34]. Entomopoxviruses are known to be relatively host specific [60] and the virulence of the imported EPV against acridids other than its direct grasshopper host may be low.

\section{Alternative Control Strategies}

The regular and often intense outbreaks of the brown locust present a formidable pest control problem. Locust control operations have evidently failed as they have been unable to stop the regular plague cycles from developing [22]. The typical large-scale incipient upsurges over a wide area of the Karoo are impossible to prevent and once the populations develop into gregaria phase eruptions then the only option is to undertake a large-scale and expensive chemical control campaign. However, chemical control operations are rarely able to subdue the large-scale eruptions on their own and such extensive control campaigns are usually assisted by the onset of unfavourable dry or cold climatic conditions that restricts further locust breeding and supresses the eruptions. Fipronil (Adonis ${ }^{\circledR}$ ) barrier treatments and insecticide baits were considered to have sufficient potential to be incorporated into an integrated management strategy against brown locust hopper bands in certain areas of the Karoo. Although there is concern regarding the environmental impact of fipronil, the barriers could have potential if judiciously applied to intercept marching hopper bands in the more remote areas of the Karoo, while insecticide baits could have application in specific areas where a low environmental impact was required. However, no alternative control method was considered sufficiently flexible and effective enough under all field conditions to entirely replace the application of synthetic pyrethroid insecticides in the Karoo. Fast-acting ULV insecticides will hence continue to provide the backbone of the brown locust control programme for the foreseeable future.

The current 'Commando' system of ground-based locust control has been in operation for decades in the Karoo, partly because it has provided a relatively cost-effective strategy against the unpredictable intensity and distribution of brown locust outbreaks across the Karoo, while also ensuring that Government finances are channelled to pay local inhabitants to fight the locusts as temporary employees when needed. However, the tracking down and spraying of thousands of individual hopper bands and roosting swarms has long been considered as an inefficient use of manpower and resources. Records dating back to the mid-1960s and again confirmed in the 1990s showed that the targeting the hopper bands accounted for up to $90 \%$ of the locust control budget, but only accounted for $10 \%$ 
of the actual number of locusts controlled, whereas the targeted spraying of roosting adult swarms accounted for an estimated $90 \%$ of the locust population $[61,62]$. In recent years, the traditional Commando system has also become more difficult to sustain due to the spiralling costs of transport and insecticides, as well as the costs of hiring the large temporary labour force. The ongoing depopulation of farms in the more remote and arid areas of the Karoo means that there is a very low density of resident farmers left to report the locusts. In addition, the changing attitudes of some landholders towards reporting locusts due to their conservation views on the spraying of pesticides, or more especially regarding the security concerns on the farms, has therefore limited access to farms for locust surveys and has negatively impacted the efficacy of the locust reporting and control network. Outbreaks on the large-sized farms in the remote Central Karoo and Bushmanland areas therefore often go undetected and the local control capacity can be suddenly overwhelmed by swarm escapes.

Alternative strategies of combatting outbreaks in the remote areas of the Karoo are required as an alternative to the traditional active location and spot spraying of individual locust targets. There is therefore a need to discuss possible alternative strategies based on sound economic and logistical principals.

\subsection{Abandoning Brown Locust Control Entirely}

Historical records showed that the uncontrolled brown locust plagues in the past (before 1940) all eventually collapsed due to a combination of factors including the buildup of natural enemies and diseases, the onset of unfavourable climatic conditions, or as a result of the exodus of swarms into areas that were unsuitable for further breeding, e.g., the mountain Kingdom of Lesotho. Earlier plague cycles were then always followed by a long recession period since the swarming populations had all vacated the optimal breeding areas in the Karoo [12,22]. By not controlling locust outbreaks, it can be argued that the outbreaks will always come to an end naturally and the money saved on control operations could be used instead to compensate for crop losses. However, the uncontrolled brown locust plague cycles between 1890 and 1940, as well as the various invasions of red locust and African migratory locust plagues into South Africa during this time, posed a devastating threat to agricultural production throughout southern Africa, causing the threat of starvation amongst rural communities. The South African and other African Governments will not tolerate this threat to food security again.

There is still an economic and environmental debate on whether locusts and grasshoppers should be chemically controlled to protect rangeland grazing [32], especially in the Karoo where the cost of locust control per hectare is usually far more than the grazing value of the land [63]. However, other studies estimated the amount of grass consumed by the brown locust hoppers and correlated this with the consumption by sheep, suggesting that it was economically viable to control the locusts in the Karoo to save the available grazing for the sheep flocks [64]. To counter these findings, it can be argued that most of the locust control operations are undertaken against late instar hopper bands and fledgling swarms when the damage to the local grazing has already been done. There is no doubt, however, regarding the need to control locust and grasshopper outbreaks within the rangeland areas to protect vulnerable staple food crops such as maize, wheat and millet grown outside the rangeland areas $[32,65]$. Likewise in the Karoo, the brown locust problem will have to be continually managed and contained within the outbreak area so that damage to food crops outside the Karoo is prevented as much as possible.

\subsection{Update the Current "Commando System"}

Within the Upper Karoo region (e.g., area containing the Districts of Prieska, Douglas, Strydenburg, Britstown, De Aar, Philipstown, Hopetown, Hanover, Richmond, Victoria West), as well as the adjacent Districts to the east and south-east, there is a higher population of resident farmers and farm workers on the relatively smaller-size farms (2000-5000 ha), as well as a good communication network. In these areas, the traditional Commando system 
of locust control can still work well once the manpower and operational resources are in place and is generally considered to be a viable and cost-effective strategy for brown locust control. However, in the more remote western areas of the arid Bushmanland and the Central Karoo, the Commando system has become ineffective due to the demographic and economic factors discussed earlier. If the Commando system is still to be applied throughout the Karoo it will have to be modernised and substantially resourced to improve the capacity to locate locust targets by implementing an effective locust monitoring and outbreak early warning system. This implies a substantial investment in regular monitoring of known locust outbreak 'hot-spot' areas, as well as resources for the implementation of technologies for effective target location and mapping systems to support the Commando teams. It is also highly recommended that the control teams should focus on the spraying of the fledgling swarms as they coalesce, as well as the larger-sized hopper bands as they aggregate, rather than spending most of their time and resources tracking down and spraying individual small-sized hopper band targets.

There are various digital field tools and GIS mapping systems used in locust control forecasting and field control operations in other parts of the world, such as the FAO's recently introduced 'eLocust3' system used in the desert locust campaigns. Survey teams can log the local survey observation data, as well as information on local climatic and vegetation conditions, onto a digital tablet that then transmits the data via satellite to a national locust command centre. All the data is precisely GPS geo-referenced and the survey or control data is then automatically downloaded onto the FAO's 'RAMSESv4' database software application and GIS mapping platform, which can combine multiple observation inputs along with dedicated layers of GIS spatial information to generate visual maps of the target areas. The GIS maps are then a powerful tool for early warning forecasting, or for directing field control operations.

Climate monitoring and vegetation greening index satellites are also employed for wide-scale desert locust forecasting in order to monitor rainfall events, soil moisture conditions and vegetation greening in remote desert regions. Such technology is readily available in South Africa and should be adopted by the brown locust management strategy to assist with outbreak forecasting. Likewise, there are sophisticated climatic models used in crop yield forecasting that could be readily adopted to model and predict rainfall conditions in the Karoo over the medium-term. The use of unmanned aerial vehicles (drones) is also showing potential for locust survey work in desert locust campaigns and can be used to locate green vegetation zones in desert areas where locusts are likely to aggregate and oviposit. The survey and location of isolated ecotone areas of tall grass and open bare patches of soil typically suitable for brown locust adult aggregation and for nearby oviposition, defined as the locust 'concentration belts' [16], could certainly benefit the locust survey teams in the Karoo by reducing the need for the extensive foot surveys.

\subsection{Abandon Hopper Control and Target Adult Swarms Only}

Using modern spray aircraft to target young swarms as they mill around and aggregate into large-size targets is standard control strategy in various countries, such as Australia and Madagascar. The similar convergence and coalescence of brown locust swarms into large swarm targets has also been regularly observed in the Karoo [61], Price, pers. obs. Apart from the high work rate of spray aircraft and the large areas that can be quickly spayed, adult locusts are also known to be more susceptible targets to kill with insecticides than late instar hoppers, which has important consequences for reduced insecticide application and environmental impact. Aircraft would only be brought into operation once a threshold number or size of swarms had developed and once cereal crops were threatened. The co-ordinated air-to-air spraying of flying swarms using low dosages of synthetic pyrethroid insecticides, accurately applied from aircraft fitted with GPS systems can effectively control even large-scale plagues. The active spotting and tracking of swarms could be done along strategically placed observation stations. 
A limited number of small to medium capacity spray aircraft, such as the Piper Pawnee, Gippsland GA200C and the Air Tractor series, could intercept large-size swarms as they aggregated and migrated along their traditional seasonal flyways out of the Central and Upper Karoo. The active spotting and tracking of swarms could be done along strategically placed observation stations. Aircraft operating from the larger towns in the Upper Karoo, such as De Aar, Britstown and Hopetown, could attack swarms once they entered a 100-150 km wide buffer zone stretching along the Orange River. Outbreaks in the Great Karoo could be controlled with aircraft stationed at Beaufort West or other suitable locations. Small-scale outbreaks may even be managed with microlight aircraft equipped with appropriate spray gear for ULV application, as has been demonstrated in earlier trial work carried out by the ARC-PHP.

\section{Conclusions}

The current Commando system of managing the brown locust is only considered as being viable and effective in the Upper and eastern Karoo regions where there is a sufficient density of resident farmers and farm workers who can report outbreaks and where good communications exist to be able to rapidly respond and obtain access to the locust targets. However, the Commando system is not currently effective over a vast area of the Central and Great Karoo and Bushmanland. The scattered outbreaks throughout these areas should be left to fledge into adult swarms, which would then soon aggregate into large-sized swarms that would make viable targets for spray aircraft. The benefits (pros) and constraints (cons) of the alternative brown locust control strategies discussed are summarized in Table 3.

Table 3. Comparison of current and alternative strategies to manage the brown locust.

\begin{tabular}{|c|c|c|}
\hline $\begin{array}{c}\text { Control Strategies, } \\
\text { Current and Alternatives }\end{array}$ & Benefits (pros) & Constraints (cons) \\
\hline 0-'Commando' system & $\begin{array}{l}\text { Current strategy. Long history, } \\
\text { community-based system, local knowledge } \\
\text { and communication networks, per diem } \\
\text { payments to local people for operations, } \\
\text { good control of small outbreaks and able to } \\
\text { dampen large upsurges. Spray roosting } \\
\text { swarms at night so more time to control } \\
\text { large-size targets. }\end{array}$ & $\begin{array}{l}\text { Not effective in some areas, weak reporting } \\
\text { from remote farms, reduced access to all } \\
\text { farms, mainly target L5 bands so not cost } \\
\text { effective, not able to stop large upsurges or } \\
\text { prevent plague cycles. No central } \\
\text { coordination of operations or situation } \\
\text { over-view, no early warning or mapping of } \\
\text { outbreaks, sub-optimal use of strategic } \\
\text { resources. }\end{array}$ \\
\hline $\begin{array}{l}\text { 1-Abandoning brown locust } \\
\text { control entirely }\end{array}$ & $\begin{array}{l}\text { With natural enemies and diseases, } \\
\text { unfavourable climatic conditions, exodus of } \\
\text { swarms into unsuitable areas, outbreaks will } \\
\text { always end naturally. Ecologically } \\
\text { sustainable. } \\
\text { Money saved on control operations could be } \\
\text { used to compensate for crop losses. No } \\
\text { environmental damage from pesticides. }\end{array}$ & $\begin{array}{l}\text { Large-scale outbreaks cause severe damage } \\
\text { to Karoo grazing, widespread damage to } \\
\text { commercial cereal crops outside the Karoo, } \\
\text { threat of starvation amongst smallholder } \\
\text { farmers and rural communities. } \\
\text { Swarm invasions into neighbouring } \\
\text { countries, political pressure on South Africa } \\
\text { to contain locust outbreaks. }\end{array}$ \\
\hline $\begin{array}{l}\text { 2-Update the current } \\
\text { "Commando system" }\end{array}$ & $\begin{array}{c}\text { Adoption of modern GIS technology for } \\
\text { target reporting and campaign management, } \\
\text { more focus on control of aggregating swarms, } \\
\text { more effective deployment of resources, } \\
\text { better planning and direction of operations, } \\
\text { more tactical use of spray aircraft } \\
\text { when required. } \\
\text { A viable and cost-effective strategy for brown } \\
\text { locust control in some areas, such as the } \\
\text { Upper and eastern Karoo. Will work well } \\
\text { once the manpower and operational } \\
\text { resources are in place. }\end{array}$ & $\begin{array}{c}\text { Outdated and not currently effective over a } \\
\text { vast area of the Central and Great Karoo and } \\
\text { Bushmanland. } \\
\text { Substantial investment necessary in new } \\
\text { technologies. } \\
\text { Will still have weak reporting of targets in } \\
\text { remote areas, risk of sub-optimal adoption } \\
\text { and use of technologies. Fewer locust control } \\
\text { teams required-loss of income for } \\
\text { communities. Availability, coordination and } \\
\text { high costs of spray aircraft. }\end{array}$ \\
\hline
\end{tabular}


Table 3. Cont.

\begin{tabular}{|c|c|c|}
\hline $\begin{array}{l}\text { Control Strategies, } \\
\text { Current and Alternatives }\end{array}$ & Benefits (pros) & Constraints (cons) \\
\hline $\begin{array}{l}\text { 3-Abandon hopper control and } \\
\text { target adult swarms only }\end{array}$ & $\begin{array}{l}\text { Adult swarms naturally coalesce to form } \\
\text { large targets. Adult locusts are known to be } \\
\text { more susceptible targets to kill with } \\
\text { insecticides than late instar hoppers. } \\
\text { Farmers and locust officers spot and report } \\
\text { the swarms, limited number of small to } \\
\text { medium capacity spray aircraft required. } \\
\text { Sophisticated commercial aerial spray } \\
\text { companies in South Africa. } \\
\text { Reduced insecticide application and } \\
\text { environmental impact. }\end{array}$ & $\begin{array}{l}\text { During large outbreaks adult populations } \\
\text { develop simultaneously over wide areas, } \\
\text { swarm spotting capacity and spray aircraft } \\
\text { resources overwhelmed, massed swarm } \\
\text { escapes from the Upper and eastern Karoo. } \\
\text { More locust damage to Karoo grazing and } \\
\text { increased threat to cereal crops outside Karoo. } \\
\text { Political pressure from commercial farmers } \\
\text { and rural communities, swarm invasion of } \\
\text { neighbouring countries. }\end{array}$ \\
\hline $\begin{array}{l}\text { 4-Necessity of an IPM approach } \\
\text { Modernised and well-resourced } \\
\text { Commando system in the Upper } \\
\text { Karoo and eastern Karoo, } \\
\text { spraying fledgling swarms and } \\
\text { large hopper bands. } \\
\text { + } \\
\text { Stop using ground-based } \\
\text { 'Commando' system in remote } \\
\text { areas of central and western } \\
\text { Karoo where ineffective and } \\
\text { switch mainly to aircraft control } \\
\text { of aggregating swarms. }\end{array}$ & $\begin{array}{l}\text { Modernize and support Commando system } \\
\text { in Upper and eastern Karoo. } \\
\text { Stop wasting finances and resources with } \\
\text { current ineffective system in remote areas. } \\
\text { Locust officers now employed to spot and } \\
\text { track aggregating swarms and to direct spray } \\
\text { aircraft to targets. } \\
\text { Use modern technology to map outbreaks } \\
\text { and to direct ground operations and aircraft } \\
\text { campaign. More effective allocation of } \\
\text { manpower and resources. More effective kill } \\
\text { of locusts (dead locusts per litre } \\
\text { of insecticide). }\end{array}$ & $\begin{array}{l}\text { Farmer political pressure that remote areas of } \\
\text { Karoo are being 'neglected', loss of potential } \\
\text { income for locust officers and spray teams. } \\
\text { Manpower for spotting and tracking swarm } \\
\text { targets in remote areas. Availability and } \\
\text { coordination of aircraft for swarm control. } \\
\text { High costs of hire aircraft capacity. New ULV } \\
\text { formulations required for aircraft. Short } \\
\text { window to spray roosting swarm targets in } \\
\text { the morning. }\end{array}$ \\
\hline
\end{tabular}

When reviewing possible options for controlling the brown locust, the most effective strategy probably lies with an integrated locust management strategy, with a modernised and well-resourced Commando system in the Upper Karoo and eastern Karoo that focusses on the spraying of coalescing fledgling swarms and the larger hopper band targets, supported by the judicious use of aircraft for the aerial control of swarms developing in the more remote regions of the Karoo. Such an integrated strategy combining ground and aerial tactics would have the flexibility and the capacity to deal effectively with all locust emergencies. It is also vital to invest more resources in technology for the early-warning forecasting of brown locust outbreaks in relation to climatic conditions, along with timely surveys of known outbreak hot-spot farms early in the season. The use of digital technology data gathering and mapping systems would also enhance the ability to manage the outbreaks as they developed and would allow resources to be deployed more judiciously.

Funding: Received from the ARC-Plant Health and Protection.

Institutional Review Board Statement: Not applicable.

Informed Consent Statement: None applicable.

Data Availability Statement: Data sharing not applicable.

Acknowledgments: To my late colleagues and mentors, Dick Brown and Peter Napier-Bax, for their camaraderie on our numerous locust field trips throughout the Karoo. Thanks to the many hospitable Karoo farmers who allowed us to work on their land and to the locust officers who enthusiastically guided us to the locust targets. Thanks to the ARC-Plant Health and Protection for the financial and administrative support, as well as the various Agro-Chemical companies and to CABI for financial support for specific projects within the study. Thanks to the South African Department of Agriculture for providing the weekly locust control data and to my colleague, Margaret Kieser, for analysing and computing the locust data.

Conflicts of Interest: The author declares no conflict of interest. 


\section{References}

1. Faure, J.C.; Marais, S.J.S. The control of Locustana pardalina in its outbreak centres. In Proceedings of the 4th International Locust Conference, Cairo, Egypt, 22 April 1936. 5p.

2. Du Plessis, C. The Influence of Weather Conditions on the Incipient Swarming of the Brown Locust, Locustana Pardalina (Walker); Science Bulletin, Department of Agriculture and Forestry, Union of South Africa Government Printer: Pretoria, South Africa, 1938; Volume 186, pp. 1-51.

3. Lea, A. Recent outbreaks of the brown locust with special reference to the influence of rainfall. J. Entmol. Soc. S. Afr. 1958, 21, 162-213.

4. Kieser, M.E.; Thackrah, A.; Rosenberg, J. Changes in the outbreak region of the brown locust in Southern Africa. Grootfontein Agric. 2002, 4, 20-23. Available online: http://gadi.agric.za/articles/Kieser_M/kieser_vol4_2002_locust.php (accessed on 9 August 2021).

5. Du Plessis, C. The Incipient Outbreaks of the Brown Locust in 1937-1938 with Special Reference to Biometrical Analysis; Science Bulletin, Department of Agriculture and Forestry, Union of South Africa Government Printer: Pretoria, South Africa, 1939; Volume 209, pp. 1-69.

6. Faure, J.C. The phases of locusts in South Africa. Bull. Entmol. Res. 1932, 23, 293-405. [CrossRef]

7. Uvarov, B.P. Grasshoppers and Locusts; Cambridge University Press: Cambridge, UK, 1966; Volume 2.

8. Faure, J.C. The life history of the brown locust. J. Dept. Agric. Union S. Afr. 1923, 4, 205-224.

9. Potgieter, J.T. A Contribution to the Biology of the Brown Swarm Locust and Its Natural Enemies; Science Bulletin, Department of Agriculture and Forestry, Union of South Africa Government Printer: Pretoria, South Africa, 1929; Volume 82, pp. 1-48.

10. Smit, C.J.B. Field Observations on the Brown Locust in an Outbreak Centre; Science Bulletin, Department of Agriculture and Forestry, Union of South Africa Government Printer: Pretoria, South Africa, 1939; Volume 190, pp. 1-143.

11. Smit, C.J.B. The behaviour of the brown locust in its solitary phase. In Technical Communication; Department of Agricultural and Technical Services: Pretoria, South Africa, 1960; Volume 1, pp. 1-132.

12. Lea, A. Natural regulation and artificial control of brown locust numbers. J. Entomol. Soc. S. Afr. 1968, 31, 89-112.

13. Lea, A. The distribution and abundance of brown locusts between 1954 and 1965. J. Entomol. Soc. S. Afr. 1969, 32, 367-398.

14. Matthee, J.J. The Structure and Physiology of the Egg of Locustana pardalina (Walker); Science Bulletin, Department of Agriculture and Forestry, Union of South Africa Government Printer: Pretoria, South Africa, 1951; Volume 316, pp. 1-83.

15. Botha, D.H. The viability of brown locust eggs, Locustana pardalina (Walker). S. Afr. J. Agric. Sci. 1967, 10, 445-460.

16. De Wet, W.J.; Webb, D. Field observations on the behaviour of hoppers of the brown locust in the swarming phase; Science Bulletin, Department of Agriculture and Forestry, Union of South Africa. Government Printer: Pretoria, South Africa, 1951; Volume 337, pp. 1-38.

17. Price, R.E. The life cycle of the brown locust, with reference to egg viability. In Proceedings of the Locust Symposium, MacGregor Museum, Kimberley, South Africa, 11-13 May 1987; Mckensie, B., Longridge, M., Eds.; South African Institute of Ecologists Bulletin, Special Issue: Rondebosch, South Africa, 1988; pp. 27-40.

18. Lounsbury, C.P. The locust invasion. Agricultural Journal of the Cape of Good Hope; Department of Agriculture, Cape of Good Hope: Cape Town, South Africa, 1906; pp. 596-600.

19. Price, R.E.; Brown, H.D. A century of locust control in South Africa. In Proceedings of the Workshop on Research Priorities for Migrant Pests of Agriculture in Southern Africa, PPRI, Pretoria, South Africa, 24-26 March 1999; Cheke, R.A., Rosenburg, L.J., Kieser, M.E., Eds.; Natural Resources Institute: Chatham, UK, 2000; pp. 37-50.

20. Lounsbury, C.P. Some phases of the locust problem. S. Afr. J. Sci. 1915, 11, 33-45.

21. Lea, A. Some major factors in the population dynamics of the brown locust, Locustana pardalina (Walker). Monogr. Biol. 1964, 14, 269-283.

22. Lea, A. The plague dynamics of the brown locust, Locustana pardalina (Walk.). In Proceedings of the International Study Conference on Current and Future Problems of Acridology, London, UK, 6-16 July 1970; Hemming, C.F., Taylor, T.H.C., Eds.; Centre for Overseas Pest Research: London, UK, 1970; pp. 289-297.

23. Lecoq, M. Recent progress in Desert and Migratory locust management in Africa. Are preventative actions possible? J. Orthoptera Res. 2001, 10, 271-276. [CrossRef]

24. Brown, H.D.; Bashir, E.A. Criteria for classification of brown locust outbreaks. In Proceedings of the 4th Meeting of the Migratory Pests Sub-Committee of the Southern African Regional Commission for the Conservation and Utilization of the Soil (SARCCUS), Windhoek, Namibia, 4-6 June 1990.

25. Mally, C.W. Arsenite of soda as a locust poison. J. Dept. Agric. Union. S. Afr. 1923, 13, 1-15.

26. Policy for Managing the Locust Problem in South Africa. National Department of Agriculture. September 1988. Available online: https:/ / www.nda.agric.za/docs/policy/policy98.htm (accessed on 9 August 2021).

27. Peters, S.M.; Lindeman, H.; van der Westhuizen, M.C. Locust control data analysis: Environmental, manpower and financial analysis of locust control in South Africa. In Proceedings of the Workshop on Research Priorities for Migrant Pests of Agriculture in Southern Africa, PPRI, Pretoria, South Africa, 24-26 March 1999; Cheke, R.A., Rosenburg, L.J., Kieser, M.E., Eds.; Natural Resources Institute: Chatham, UK, 2000; pp. 75-87. 
28. Brown, H.D. Current pesticide application: Effectiveness and persistence. In Proceedings of the Locust Symposium, MacGregor Museum, Kimberley, South Africa, 11-13 May 1987; Mckensie, B., Longridge, M., Eds.; South African Institute of Ecologists Bulletin, Special Issue: Rondebosch, South Africa, 1988; pp. 101-117.

29. Nailand, P.; Hanrahan, S.A. Modelling brown locust, Locustana pardalina (Walker), outbreaks in the Karoo. S. Afr. J. Sci. 1993, 89, 420-424.

30. Todd, M.C.; Washington, R.; Cheke, R.A.; Kniverton, D. Brown locust outbreaks and climate variability in southern Africa. J. App. Ecol. 2002, 39, 31-42. [CrossRef]

31. Riegert, P.W.; Ewen, A.B.; Lockwood, J.A. A history of chemical control of grasshoppers and locusts 1940-1990. In The Bionomics of Grasshoppers, Katydids and Their Kin; Gangwere, S.K., Muralirangan, M.C., Muralirangan, M., Eds.; CAB International: Wallingford, UK, 1997; pp. 385-405.

32. Peveling, R. Environmental conservation and locust control-Possible conflicts and solutions. J. Orthoptera Res. 2001, 10, 171-187. [CrossRef]

33. Stewart, D.A.B. Non-target grasshoppers as indicators of the side effects of chemical locust control in the Karoo, South Africa. J. Insect Conserv. 1998, 2, 263-276. [CrossRef]

34. Price, R.E. Alternative Methods of Controlling the Brown Locust, Locustana pardalina (Walker). Ph.D. Thesis, University of the Free State, Bloemfontein, South Africa, 2003; pp. 1-152. Available online: http://hdl.handle.net/11660/6227 (accessed on 9 August 2021).

35. Botha, D.H.; Lea, A. Do brown locust periods come in cycles? Farming S. Afr. 1970, 387, 1-5.

36. Erasmus, B.H. Natural predators and parasites of the brown locust-an ecological appraisal. In Proceedings of the Locust Symposium, MacGregor Museum, Kimberley, South Africa, 11-13 May 1987; Mckensie, B., Longridge, M., Eds.; South African Institute of Ecologists Bulletin, Special Issue: Rondebosch, South Africa, 1988; pp. 118-137.

37. Van Schalkwijk, H.A.D. The status of Wohlfahrtia euvitatta Vill. (Diptera, Sarcophagidae) as a parasite of the brown locust. J. Entmol. Soc. Sth. Afr. 1939, 2, 18-35.

38. Price, R.E.; Brown, H.D. The status of the locust fly, Wohlfahrtia pachytyli (Diptera: Sarcophagidae), in the Karoo and the impact of locust control operations on its abundance. Afr. Entmol. 2006, 14, 35-43.

39. Anonymous. First Report of the Committee of Control of the South African Central Locust Bureau; Fuller, C., Ed.; Republic of South Africa, Locust Control and Research, Department of Agriculture, Cape of Good Hope: Cape Town, South Africa, 1907; Volume 1.

40. Du Plessis, C.; Botha, D.H. Preliminary field experiments on the attractiveness of certain chemicals and bait carriers to hoppers of the brown locust. J. Entomol. Soc. S. Afr. 1939, 2, 74-92.

41. Price, R.E.; Brown, H.D. Locust control by means of selective baiting. In New Strategies for Locust Control; Krall, S., Peveling, R., Ba Diallo, D., Eds.; Birkhäuser: Basel, Switzerland, 1997; pp. 209-217.

42. Bennett, L.V.; Symmons, P.M. A review of the effectiveness of certain control techniques against the Desert locust. Anti. Locust Bull. 1972, 50, 1-15.

43. Brader, L. Control of grasshopper and migratory locusts. In Proceedings of the Crop Protection Conference (Pests and Diseases), Brighton, UK, 21-24 November 1988; pp. 283-288.

44. Matthews, G.A. The Pesticide Referee Group of FAO and its contribution to locust control. J. Orthoptera Res. 2005, 14, 203-206. [CrossRef]

45. Everts, J.W. Environmental Effects of Chemical Locust and Grasshopper Control. A Pilot Study Project ECLO/SEN/003/NET; FAO: Rome, Italy, 1990; 227p.

46. Neuman, R.; Guyer, W. Biochemical and toxicological differences in the mode of action of the benzoylureas. Pest. Sci. 1987, 20, 147-156. [CrossRef]

47. Bateman, R.P. The development of a mycoinsecticide for the control of locusts and grasshoppers. Outlook Agric. 1997, 26, 13-18. [CrossRef]

48. Lomer, C.J.; Prior, C.; Kooyman, C. Development of Metarhizium spp. for the control of grasshoppers and locusts. Mem. Entomol. Soc. Canada 1997, 171, 265-286. [CrossRef]

49. Food and Agriculture Organisation of the United Nations. Evaluation of Field Trial Data on the Efficacy and Selectivity of Insecticides on Locusts and Grasshoppers. In Proceedings of the Report to FAO by the Pesticide Referee Group, 8th Meeting, Rome, Italy, 11-14 October 1999. Available online: http://www.fao.org/ag/locusts/common/ecg/800_en_PRG08e.pdf (accessed on 9 August 2021).

50. Love, G.; Riwoe, D. Economic Costs and Benefits of Locust Control in Eastern Australia. ABARE eReport 05.14 Prepared for the Australian Plague Locust Commission; Australian Bureau of Agricultural and Resource Economics: Canberra, Australia, 2005.

51. Bateman, R.P.; Price, R.E.; Müller, E.J.; Brown, H.D. Controlling brown locust hopper bands in South Africa with a mycoinsecticide spray. In Proceedings of the Crop Protection Conference (Pests and Diseases), Brighton, UK, 21-24 November 1994; Volume 2, pp. 609-616.

52. Price, R.E.; Bateman, R.P.; Brown, H.D.; Butler, E.T.; Müller, E.J. Aerial spray trials against brown locust, Locustana pardalina (Walker), nymphs in South Africa using an oil- formulation of Metarhizium flavoviride. Crop Prot. 1997, 16, 345-351. [CrossRef]

53. Müller, E.J. Control of the brown locust, Locustana pardalina (Walker) (Orthoptera: Acrididae), using a myco-insecticide: Addressing the issues of speed of kill, dose rate, mortality and reduction in feeding. Afr. Entmol. 2001, 8, $217-221$. 
54. Blanford, S.; Thomas, M.B. Thermal behaviour of two acridid species: Effects of habitat and season on body temperature and the potential impact on biocontrol with pathogens. Environ. Entmol. 2000, 29, 1060-1069. [CrossRef]

55. Arthurs, S.P.; Thomas, M.B. Effects of a mycoinsecticide on feeding and fecundity of the brown locust, Locustana pardalina. Biocontrol. Sci. Technol. 2000, 10, 321-329. [CrossRef]

56. Streett, D.A.; McGuire, M.R. Pathogenic diseases of grasshoppers. In Biology of Grasshoppers; Chapman, R.F., Joern, A., Eds.; John Wiley \& Sons: New York, NY, USA, 1990; pp. 483-516.

57. Streett, D.A.; Woods, S.A.; Erlandson, M.A. Entomopoxviruses associated with grasshoppers and locusts: Biology and biological control potential. In Microbial Control of Grasshoppers and Locusts; Goettel, M.S., Johnson, D.L., Eds.; Memoirs of the Entomological Society of Canada: Ottawa, ON, Canada, 1997; Volume 171, pp. 115-130.

58. Zelazny, B.; Goettel, M.S.; Keller, B. The potential of bacteria for the microbial control of grasshoppers and locusts. In Microbial Control of Grasshoppers and Locusts; Goettel, M.S., Johnson, D.L., Eds.; Memoirs of the Entomological Society of Canada: Ottawa, ON, Canada, 1997; Volume 171, pp. 147-156.

59. Streett, D.A. Future prospect for microbial control of grasshoppers. In Integrated Pest Management on Rangeland; Capinera, J.L., Ed.; Westview Press: Boulder, CO, USA, 1987; pp. 205-218.

60. Prior, C.; Greathead, D.J. Biological Control of Locusts: The Potential for the Exploitation of Pathogens. FAO Plant Prot. Bull. 1989, $37,37-48$.

61. Cilliers, J.; van Someren-Greve, J.; Lea, A. A case of converging swarms of the brown locust and implications for control strategy. S. Afr. J. Agric. Sci. 1964, 7, 867-874.

62. Steenkamp, D.; Botha, T.; van der Westhuizen, L. Cost benefit analysis of locust control in South Africa. In Insects in African Entomology and Environment, Proceedings of the Joint Conference Entomological Society of South Africa (11th Congress) and the Africa Association Insect Scientists (12th Congress), Stellenbosch, South Africa, 30 June-4 July 1997; Entomological Society of Southern Africa: Pretoria, South Africa, 1997; p. 81.

63. Esler, K.J.; Milton, S.J.; Dean, W.R.J. Karoo Veld: Ecology and Management; Briza Publications: Pretoria, South Africa, 2010; 214p.

64. Coetsee, J.C. Weidingsimpak van Die Bruinsprinkaan, Locustana pardalina (Walker) in Die Karoo-Uitbraakgebiet. Master's Thesis, University of Free State, Bloemfontein, South Africa, 1994; 132p.

65. Krall, S.; Herok, C. Economics of desert locust control. In New Strategies for Locust Control; Krall, S., Peveling, R., Ba Diallo, D., Eds.; Birkhäuser: Basel, Switzerland, 1997; pp. 401-414. 